\title{
РОЛЬ МЕДИЧНОЇ СЕСТРИ У НАДАННІ МЕДИЧНОЇ ДОПОМОГИ ХВОРИМ НА АРТЕРІАЛЬНУ ГІПЕРТЕНЗІЮ
}

Роль медичної сестри у наданні медичної допомоги хворим на артеріальну гіпертензію

\section{H. І. Рега, О. Р. Рега}

Тернопільський національний медичний університет імені І. Я. Горбачевського МОЗ України

Резюме. Артеріальна гіпертензія - че найпоширеніше хронічне захворювання серцево-судинної системи, яке уражає людей працездатного віку і призводить до розвитку тяжких ускладнень та інвалідизації. Контроль за артеріальним тиском - один з основних моментів лікування артеріальної гіпертензії. У цьому аспекті важлива роль відводиться роботі медичної сестри з пацієнтами.

Мета дослідження - розробити стандартизовані фрункції з надання медичної допомоги хворим на АГ медичної сестри кабінету сімейного лікаря або терапевта.

Матеріали і методи. На даному етапі реформування медичної галузі вирішальне місце у боротьбі з АГ відводиться ланці первинної медико-санітарної допомоги (ПМСД). Відомо, що ефективність їі роботи залежить від чіткої і узгодженої командної взаємодії сімейного лікаря (дільничого терапевта) та медичної сестри. Сучасна медична сестра амбулаторії ПМСД бере активну участь у всіх етапах організації надання медичної допомоги хворим на $А Г$, зокрема бере участь у діагностиці АГ, лікувальному процесі, здійснює первинну профрілактику АГ та проводить диспансерний нагляд за хворими на $А Г$.

Результати. У даній статті показано переваги надання медичної допомоги хворим з артеріальною гіпертензією разом у команді з лікарем. Запропоновано стандарт медсестринської допомоги хворим на артеріальну гіпертензію.

Висновки. Ефективність роботи ланки первинної медико-санітарної допомоги залежить від чіткої $i$ узгодженої командної взаємодії сімейного лікаря (дільничого терапевта) та медичної сестри загальної практики - сімейної медицини (амбулаторії ПМСД). Сучасна медична сестра бере активну участь у всіх етапах організації надання медичної допомоги хворим на АГ. Розробка стандартизованих функцій з надання медичної допомоги хворим на АГ медичної сестри кабінету сімейного лікаря або терапевта сприяє підвищенню якості надання медичної допомоги хворим на АГ.

Ключові слова: артеріальна гіпертензія; медична сестра; первинна медико-санітарна допомога.
Role of nurses in the providing of medical assistance to patients with arterial hypertension

N. I. Reha, O. R. Reha

I. Horbachevsky Ternopil National Medical University

e-mail: rega@tdmu.edu.ua

Summary. Hypertension is the most common chronic disease of cardiovascular system, which affects people of working age and leads to serious complications and disability. Blood pressure control is one of the main points in the treatment of hypertension. In this aspect, the work of the nurse with patients plays an important role.

The aim of the study - to develop standardized functions for the provision of medical care by a nurse in the office of a family doctor or therapist for patients with hypertension.

Materials and Methods. At the present stage of the reform of the medical sector, the primary role in the fight against hypertension is given to the primary health care (PHC) unit. It is known that the effectiveness of its work depends on a clear and coordinated team interaction between the family doctor (primary care physician) and the nurse. The modern nurse of the PHC outpatient clinic is actively involved in all stages of the organization of medical care for patients with hypertension, in particular participates in the diagnosis of hypertension, the medical process, carries out primary prevention of hypertension and conducts dispensary supervision of patients with hypertension.

Results. This article demonstrates the advantages of nursing care for patients with hypertension together with a doctor. The standard of nursing care for patients with hypertension is proposed.

Conclusions. The effectiveness of the primary health care depends on the team interaction between the family doctor and the nurse. The modern nurse has active participation in all stages of the organization of medical care for patients with hypertension. The development of standardized functions for the provision of medical care for patients with hypertension nurse contributes to improving the quality of care for patients with hypertension.

Key words: arterial hypertension; nurse; primary health care. 


\section{ВСТУП}

Дослідження, які проводилися в Україні за останні десятиліття, вказують на невпинне зростання поширення та смертності від хвороб системи кровообігу $[1,2]$. Серед них вирішальне значення має артеріальна гіпертензія (АГ). Протягом останніх років також відмічають тенденцію до істотного зростання цієї патології [1]. Проблема АГ давно вийшла за рамки суто медичної. Сьогодні весь світ визначає ії як соціальну проблему, яка впливає на здоров'я суспільства і тривалість життя громадян. Україна не $є$ винятком: рівень поширення цього захворювання та смертності від нього в нашій країні досить високий [3-5]. Протягом останніх двох десятиліть в Україні істотно зросла поширеність (у 2,3 раза) та захворюваність (у 1,9 раза) на АГ. Найбільше ці показники змінилися у Південному та Південно-Східному районах України [3]. Основними причинами виникнення та поширення АГ і її ускладнень залишаються класичні чинники ризику: надмірна маса тіла та нераціональне харчування, зловживання алкоголем, тютюнокуріння, недостатня фрізична активність, а також національний економічний стан та необізнаність пацієнтів і нераціональний прийом антигіпертензивних середників [3].

Несприятлива епідеміологічна ситуація, що склалася в Україні щодо гіпертонічної хвороби і спричинених нею ускладнень, вимагає негайного вирішення на державному рівні. В умовах реформування системи охорони здоров'я України особливого значення набуває запровадження якісно нових заходів щодо профрілактики захворювань та діяльності з формування здорового способу життя. За даними офріційної статистики МО3, кожна третя людина дорослого віку сьогодні страждає від АГ. Щорічно при зверненні людей уперше до лікувально-профрілактичних закладів виявляється понад $1 \mathrm{млн} \mathrm{хворих} \mathrm{на} \mathrm{АГ} \mathrm{[5].} \mathrm{АГ} \mathrm{є} \mathrm{одним} \mathrm{із} \mathrm{основних} \mathrm{чин-}$ ників серцево-судинних захворювань. Відомо, що наявність високого артеріального тиску (АТ) провокує та пришвидшує розвиток атеросклерозу, що, у свою чергу, суттєво (у 3-4 рази) підвищує захворюваність на ішемічну хворобу серця та інсульт, а також на серцеву та ниркову недостатність, в 7 разів частіше спричиняє порушення мозкового кровообігу. Якщо проаналізувати структуру загальної смертності населення України, стає очевидним: 66,3 \% смертей є наслідком хвороб системи кровообігу. Тому усунення АГ, яка є вагомим чинником зменшення ризику серцево-судинних захворювань, сприятиме поліпшенню стану здоров'я суспільства в цілому [4].

Не викликає сумнівів, що успішна боротьба з АГ можлива. Діагностика цього захворювання не потребує великих затрат, проте значних економічних збитків для держави завдають витрати, пов'язані 3 лікуванням і реабілітацією зазначеної категорії хворих (лікарські препарати, обладнання, медичний персонал, амортизація основних фрондів тощо). Аналіз показників поширення, захворюваності, інвалідності та смертності від серцево-судинних хвороб свідчить, що значна їх частина припадає на працездатний вік. I з кожним роком гіпертензія «молодіє» [5]. В Україні, за даними епідеміологічних досліджень, стандартизований за віком показник поширеності АГ серед працездатного населення України становить 34,1 \%: серед чоловіків - 34,7 \%; серед жінок - 33,4 \%. Наявність підвищеного тиску як захворювання знають лише 46,9 \% сільських і 85,1 \% міських мешканців, лікуються відповідно усього 12,4 та 61,2 \%, 3 них ефективно - 6,2 та 20,5 \%. Отже, ситуація щодо контролю АГ незадовільна як у сільській популяції, так і в міській, проте в сільській місцевості вона вкрай несприятлива $[4,5]$.

Метою дослідження було розробити стандартизовані функції 3 надання медичної допомоги медичної сестри кабінету сімейного лікаря або терапевта хворим на АГ.

\section{МАТЕРІАЛИ I МЕТОДИ}

На сьогоднішньому етапі ресрормування медичної галузі вирішальне місце у боротьбі з АГ відводиться ланці первинної медико-санітарної допомоги (ПМСД). Відомо, що ефективність її роботи залежить від чіткої і узгодженої командної взаємодії сімейного лікаря (дільничого терапевта) та медичної сестри [6].

Сучасна медична сестра амбулаторії ПМСД бере активну участь у всіх етапах організації надання медичної допомоги хворим на АГ, зокрема бере участь у діагностиці АГ, лікувальному процесі, здійснює первинну просрілактику АГ та проводить диспансерний нагляд за хворими на АГ [7].

\section{РЕЗУЛЬТАТИ ТА ОБГОВОРЕННЯ}

Наводимо примірні обов'язки медичної сестри загальної практики - сімейної медицини (амбулаторії ПМСД).

Стандартизовані фрункції з надання медичної допомоги медичної сестри загальної практики - сімейної медицини (амбулаторії ПМСД) хворим на АГ.

1. Організація надання медичної допомоги медичної сестри хворим на АГ

Медична сестра:

1.1 Веде список пацієнтів з АГ для проведення диспансерного нагляду. Список включає наступну інформацію: прізвище, ім'я, по батькові, дату народження (у фрорматі дд.мм.рррр), адресу реєстрації та проживання, контактний телесон, діагноз, примітки (додаткова інорормація). 
1.2. Раз на рік надає пацієнту Інформаційний лист для пацієнта 3 артеріальною гіпертензією, про що робить запис у медичній документації.

1.3. Володіє методикою вимірювання артеріального тиску.

1.4. За призначенням лікаря вимірює АТ пацієнтам на прийомі.

1.5. Викликає на огляд пацієнтів із диспансерної групи за вказівкою лікаря.

1.6. Обчислює індикатори якості медичної допомоги.

2. Первинна профілактика АГ медичною сестрою.

Медична сестра:

2.1. Вимірює АТ пацієнтам.

2.2. Вимірює пацієнтам за вказівкою лікаря масу тіла, зріст та окружність талії.

2.3. Надає інформацію щодо дотримання здорового способу життя (рекомендує не курити, обмежувати вживання алкоголю, нормалізувати масу тіла тощо).

\section{3. Діагностика АГ медичною сестрою.}

Медична сестра:

3.1. Виписує направлення на обстеження відповідно до призначень лікаря.

3.2. Щодня о встановленій годині забирає результати аналізів.

3.3. Щодня інорормує лікаря про зміни (якщо вони є) в роботі ключових пунктів надання медичної допомоги.

\section{4. Лікування АГ медичною сестрою.}

Медична сестра:

4.1. Роз'яснює пацієнту особливості подальшого розвитку хвороби, надає рекомендації щодо зміни способу життя, харчування, фрізичної активності.

4.2. Рекомендує дотримуватися дієти з обмеженням споживання кухонної солі, солодощів, на- сичених жирів та збільшенням вживання фрруктів та овочів.

4.3. Заохочує пацієнтів до самоконтролю АТ.

5. Диспансерний нагляд медичної сестри за хворими на АГ.

Медична сестра:

5.1. Заповнює контрольні карти диспансерного нагляду.

5.2. Веде картотеку контрольних карт диспансерного нагляду (орорма № 030/о).

5.3. Відповідно до призначень лікаря запрошує пацієнтів на прийом за три доби до рекомендованого огляду.

5.4. Виписує направлення на обстеження відповідно до призначень лікаря.

5.5. Заповнює довідки для одержання путівки (форма № 070/о) на санаторно-курортне лікування за призначенням лікаря.

5.6. Заповнює санаторно-курортні карти (формa № 072/o).

\section{ВИСНОВКИ}

1. Ефрективність роботи ланки первинної медико-санітарної допомоги залежить від чіткої і узгодженої командної взаємодії сімейного лікаря (дільничого терапевта) та медичної сестри загальної практики - сімейної медицини (амбулаторії ПМСД).

2. Сучасна медична сестра бере активну участь у всіх етапах організації надання медичної допомоги хворим на АГ, зокрема у діагностиці АГ, лікувальному процесі, здійснює первинну профрілактику АГ та проводить диспансерний нагляд за хворими на АГ.

3. Розробка стандартизованих функцій 3 надання медичної допомоги хворим на АГ медичної сестри кабінету сімейного лікаря або терапевта сприяє підвищенню якості надання медичної допомоги хворим на АГ.

\section{СПИСОК ЛІТЕРАТУРИ}

1. Основні епідеміологічні закономірності хвороб системи кровообігу і гіпертонічної хвороби в Україні / О. М. Голяченко, А. Г. Шульгай, А. О. Голяченко [та ін.] // Вісн. соц. гігієни та орг. охорони здоров'я України. 2010. - № 4. - C. 9-15.

2. Теренда Н. О. Прогностична оцінка захворюваності та поширеності хвороб системи кровообігу / Н. О. Теренда // Вісник соц. гігієни та орг. охорони здоров'я України. - 2014. - № 4 (62). - С. 31-35.

3. Теренда Н. О. Основні тенденції загальної та первинної захворюваності на гіпертонічну хворобу в Україні // Вісник соц. гігієни та орг. охорони здоров'я України. 2015. - № 4 (66). - С. 39-43.

4. Артеріальна гіпертензія. Оновлена та адаптована клінічна настанова, заснована на доказах (2012 рік) /
Є. П. Свіщенко, А. Е. Багрій, Л. М. Єна [та ін.] // Артериальная гипертензия. - 2012. - № 1(21). - С. 96-119.

5. Уніфрікований клінічний протокол медичної допомоги. Артеріальна гіпертензія. Первинна медична допомога (догоспітальний етап). Вторинна (спеціалізована) медична допомога (2012 рік) // Артериальная гипертензия. - 2012. - № 1(21). - С. 67-95.

6. Вербіцька Л. Я. Роль медичної сестри в профрілактиці артеріальної гіпертензії / Л. Я. Вербіцька, С. О. Ястремська // Медсестринство. - 2015. - № 2. - С. 5-7.

7. Методичні підходи до розробки локальних медико-технологічних документів в закладах первинної медичної допомоги : методичний посібник для керівників центрів первинної медичної допомоги, лікарів загальної практики-сімейних лікарів / [М.К.Хобзей, Т.М.Донченко, О. В. Худошина та ін.]. - К., 2013. - 147 с. 


\section{REFERENCES}

1. Holiachenko, OM, Shulhai AH, Holiachenko AO. [The main epidemiological patterns of diseases of the circulatory system and hypertension in Ukraine]. Visn sots hihiieny ta orh. okhorony zdorovia Ukrainy. 2010;4: 9-15. Ukrainian.

2. Terenda NO. [Prognostic evaluation of morbidity and prevalence of circulatory system diseases]. Visnyk sots hihiieny ta orh. okhorony zdorov Ukrainy. 2014;4(62): 31-5. Ukrainian.

3. Terenda NO. [Main trends in general and primary incidence of hypertension in Ukraine]. Visnyk sots hihiieny ta orh okhorony zdorov Ukrainy. 2015;4(66): 39-43. Ukrainian.

4. Svishchenko YeP, Bahrii AE, Yena LM. [Hypertension. Updated and evidence-based clinical settings (2012)]. Arter giperten. 2012;1(21): 96-119. Ukrainian.
5. [Unified clinical protocol of medical care. Hypertension. Primary care. Secondary medical care (2012)]. Arter giperten. 2012;1(21): 67-95. Ukrainian.

6. Verbitska LYa, Yastremska SO. [The role of the nurse in the prevention of hypertension]. Medsestrynstvo. 2015;2: 5-7. Ukrainian.

7. Khobzei MK, Donchenko TM, Khudoshyna OV Methodical approaches to the development of local medical and technological documents in primary care facilities. [Meтодичні підходи до розробки локальних медико-технологічних документів в закладах первинної медичної допомоги] Guide for Primary Care Centers, General Practitioners and Family Physicians. Kyiv; 2013. Ukrainian. 